Kong. Res. J. 2(2) : 133-134, 2015

ISSN 2349-2694

Kongunadu Arts and Science College, Coimbatore.

\title{
IMPACT OF CLIMATE CHANGE ON THE PLANKTONS IN AKKULAM-VELI LAKE, THIRUVANANTHAPURAM DISTRICT
}

\author{
Sini Bhadrasenan Pushpangadan ${ }^{*}$ and C. Radhakrishnan Nair ${ }^{2}$ \\ ${ }^{1}$ Consultant Scientist, Malankar Social Service Society, Srothas, St. Mary's Campus, Pattom P.0, \\ Thiruvananthapuram-695 004, Kerala, India. \\ ${ }^{2}$ Assistant Professor, Department of Advanced Zoology and Biotechnology, S.T. Hindu College, Nagercoil-629 \\ 002, Kanyakumari District, Tamil Nadu, India. \\ *E.mail: siniaquarock@yahoo.in
}

\begin{abstract}
Hydrobiological studies were carried out in Akkulam - Veli (Thiruvananthapuram District, Kerala, India) estuary for six months (January - June 2008) various studies were conducted to understand the conditions of this dynamic ecosystem. The planton analysis reveals that around 64 species of phytoplankton and 8 species of zooplanktons were observed.
\end{abstract}

Keywords: Phytoplankton, zooplankton, estuary.

\section{INTRODUCTION}

The convincing definition of estuary has been given by Pritchard (1967) : "An estuary is a semi-enclosed coastal body of water which has a free connection with the open sea and within which sea water is measurably diluted with freshwater derived from land drainage". The study area, Akkulam Veli lake is a tourist attraction spot located very close to the capital city of Kerala.

The study focuses attentions on various aspects of the Environmental pollutions The Akkulam-Veli lake situated approximately $5 \mathrm{~km}$ north west of Thiruvananthapuram between latitudes 8 $25^{\prime}$ and $835^{\prime}$ and longitudes $7650^{\prime}$ and 76 58'E, the lake is having an area of $<1 \mathrm{~km}$ surrounded by lateritic hillocks. Serious environmental degradation is being experienced by this system due to municipal waste disposal, eutrophication, excessive tourism load, effluent discharge, developmental activities etc. Two canals, viz the Kulathur canal and Parvathy puthenar join the Veli lake in the northen side. The channankara canal connects the veli lake with kadinamkulam kayal in the north. Seepage of sewage from Muttathara sewage makes the water extremely polluted. Kannamoola canal joins the eastern part of the Akkulam lake. Sewage from the Thiruvananthapuram city and drainage from the suburbans are brought into the lake through the Kannammoola canal. In the vicinity of the lake there are two factories, The English clays ltd. and Travancore Titanium products ltd. The clay factory discharge and its effluents directly to the lake, while the effluent discharged from TTP to the sea finds its way to the lake when the river mouth remains open.Six stations were selected for the study they are Akkulam boat club, central part of the akkulam lake, akkulam side of the bund,central part of lake off clays factory, veli boat club, mouth part of veli lake.

\section{MATERIALS AND METHODS}

Six stations were selected for the study they are Akkulam boat club, Central part of the Akkulam lake, Akkulam side of the bund, Central part of lake off clays factory, Veli boat club, mouth part of Veli lake. The water samples were collected at the last date of every month, for a period of 6 months, starting from January 2008 to june 2008. Standard methodology after Welch (1948) and Jhingran et al. (1982), with suitable modifications to suit local availability was used. Procedures adopted are collection, preservation and transportation, washing and Qualitative analysis. The planktons were identified with the help of classical works of Prescott (1954), Desikachary $(1959,1987)$, Subramanyan (1976) and Santhanam et al. (1987).

\section{RESULTS AND DISCUSSION}

This was done for plankton analyses which reveals that around 64 species of phytoplanktons and 8 species of zooplanktons. The higher concentration of Carbondioxide resulted in low ph and high carbonate .The high concentration of Carbondioxide might be due to less photosynthetic activity because of low phytoplankton population and more respiratory acitivity of zooplankton (Bohra, 1977).The findings coincides with Bohras 
observation. The station $1 \& 2$ has maximum number of phytoplankton's compared to other stations where the concentration of carbon dioxide is less. The station $3,4,5$ \& 6 has maximum number of zooplanktons because of more carbon dioxide in that area. Thus climate change increases photosynthetic rate. The negative side of climate change is loss and degradation of habitat, effect motility of plankton disturb hydrology cycle, increases the level of UV light, pollution etc. So let us join hands with our fellowmen to the restoration of the aquatic ecosystem for our future generation.

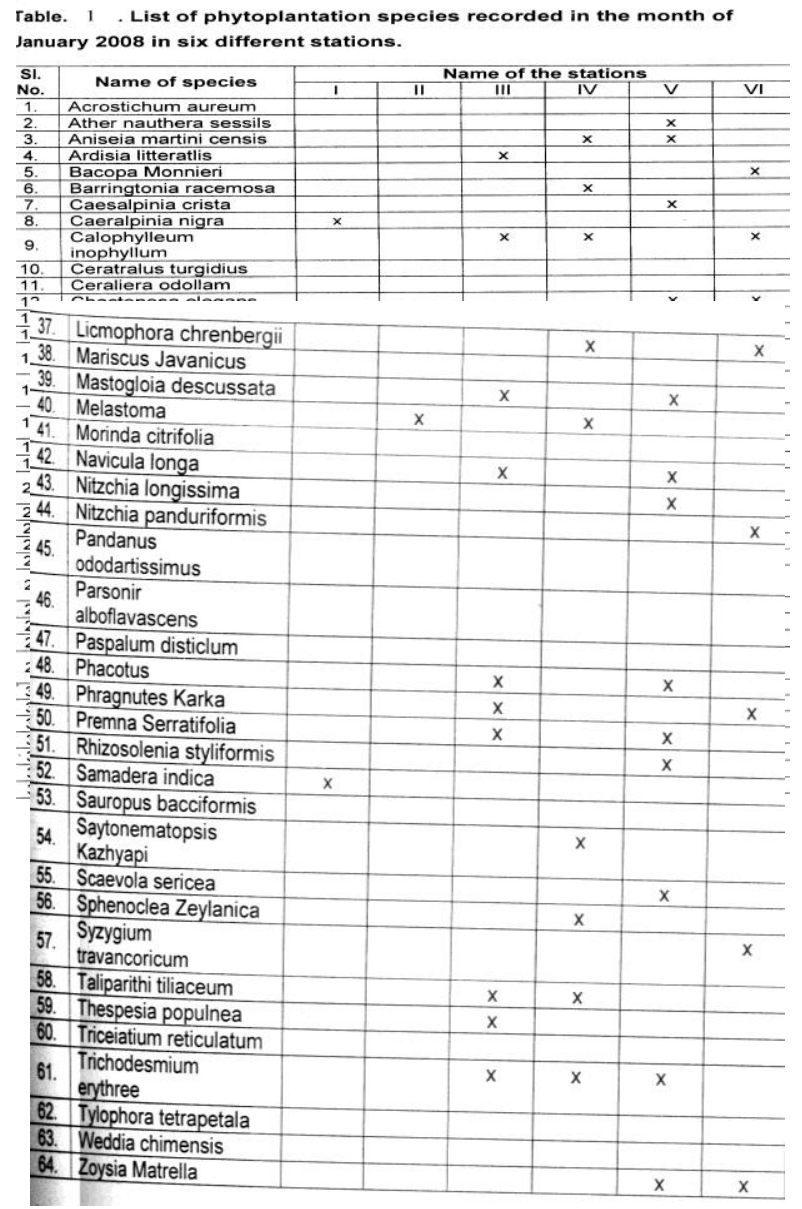

\section{REFERENCES}

Bohra, O.P. (1977). Observation on the diel cycle of abiotic parameters at Jata bera, Jodhpur.

Desikachary, T.V. (1959). Cyanophyta. Indian Council of Agricultural Research, New Delhi.

Desikachary, T.V. (1987). Atlas of Diatoms Monographs Fase I, II, III and IV. Madras Science Foundation, Madras.

Jhingran, A.G., (1982). Revised and Enlarged second Edition, Published by Hindustan Publishing Corporation, Delhi.

Prescott, G.W. (1954). How to know the freshwater algae, edited by H.E. Jacques. W.M.C. Brown Company Publishers, Jowa.

Pritchard, D.W. (1967). What is an estuary : Physical view point. In: Estuaries (G.H. Lauffed). Amer. Arroc. Adv. Sci. Puld. No. 83. Washington D.C.

Santhanam. K., and K.S. Srinivasan, (1987). Distribution patterns of marine algae in Indian seas. Proc. Symp.Algology, ICAR, New Delhi.

Subramanyan, A.N. (1976), Marine Algae; A survey of research and utilization cram de Grutyer and Co., Hamburg.

Welch, P.S. (1948). Limnological Methods. Balkiston Co. Philadelphia,Toronto. Wuhrmann, K. 1984, Lake eutrophication and its control. In: procshiga conference on conversation and

Table. 2 . List of Zooplantations recorded in the month of January 2008 in six different stations.

\begin{tabular}{|c|c|c|c|c|c|c|c|}
\hline \multirow{2}{*}{$\begin{array}{l}\text { Sl. } \\
\text { No. }\end{array}$} & \multirow{2}{*}{ Name of the species } & \multicolumn{6}{|c|}{ Name of the stations } \\
\hline & & 1 & $\|$ & III & IV & V & VI \\
\hline 1. & Cresin Spp & $x$ & $x$ & & & & \\
\hline 2. & Diphyes Spp & & & & & & \\
\hline 3. & Lalidocera acuta & $\mathrm{x}$ & & & & & \\
\hline 4. & Nauplius & & $x$ & & & & \\
\hline 5. & Sagitta Spp. & & & & & & \\
\hline 6. & Mysis & & $x$ & & & & \\
\hline 7. & Lucifer & $x$ & & & & & \\
\hline 8. & Zoea (crab) & & & & & & \\
\hline
\end{tabular}

management of world environment. 